\title{
EXCLUSION OF CHROMOSOMAL ABNORMALITIES AND MICRODELETIONS 22q11 AND 10p13 IN ALGERIAN PATIENTS WITH ISOLATED CONOTRUNCAL MALFORMATION
}

\author{
F. AMMAR-KHODJA ${ }^{1}$, M. ABDELLALI ${ }^{2}$ \\ ${ }^{1}$ Laboratory of Molecular and Cell Biology, Faculty of Biological Sciences, University USTHB, PB 32, El Alia, Algiers, Algeria \\ E-mail: fatima.khodja@gmail.com \\ ${ }^{2}$ Department of Cytology, Hammouda Laliam University Hospital, Algiers, Algeria
}

The chromosomal abnormalities of number and structure or the 22q11.2 and 10p13-14 microdeletions are considered the main causes of congenital heart disease. In our best knowledge, cytogenetics studies on congenital heart diseases (CHD) have not been performed in Algeria. In this study, we will screen for chromosomal abnormalities and microdeletions of 22q11.2 and 10p13 in a cohort of Algerian patients. G-banded by trypsin Giemsa $(G T G)$ and Fluorescent In Situ Hybridization (FISH) techniques have been performed to screen for chromosomal abnormalities and a critical regions $22 q 11.2$ and 10p 13-14 respectively in seventy patients with non syndromic congenital heart. GTG technique visualized no chromosomal abnormalities of number and structure in our patients. Moreover, FISH visualizing critical regions 22 11.2 and 10p1314 respectively did not detect any microdeletion in the chromosomes 10 and 22 respectively of our patients. Our study could suggest that congenital heart defects observed in Algerian patients are not due to chromosomal abnormalities of number and structure nor the 22q11.2 and 10p 13-14 microdeletions. For the fist time, we report here cytogenetics analysis of chromosomal abnormalities and the 22q11.2 and 10p13-14 microdeletions in Algerian patients with congenital heart disease. Genetic testing for screening for deletion $22 q 11.2$ and 10p13-14 is not indicated in all patients with isolated conotruncal defects. In addition, conotruncal heart diseases have a multifactorial background like consanguinity and recessive mutations in some genes involved in cardiac morphogenesis. A genetic study to screen for the role of consanguineous marriages and some genes linked to CHD in Algerian population is on going. This study will focus also on health education for the families at risk about the importance of pre-marital genetic counseling.

Key words: Algeria, conotruncal heart defects, FISH, chromosomal abnormalities, 22q11 microdeletion, 10p13-14 microdeletion.

Introduction. Congenital heart disease (CHD) is the most common birth defect and affects nearly $6 \%$ [1] of newborns and the aetiology of CHD is largely unknown. Chromosomal imbalances have been identified in many forms of syndromic CHD

(C) F. AMMAR-KHODJA, M. ABDELLALI, 2015
[2]. Di George syndrome (DGS) (thymus aplasia, hypoparathyroidism, facial dysmorphies and conotruncal anomalies) [3], velocardiofacial syndrome (VCFS) (cleft palate, learning disabilities, cardiac malformations) [4] and conotruncal anomaly face syndrome (CTAFS) (hypertelorism, short palpebral fissures, nasal voice, mild mental retardation and conotruncal cardiac anomalies) [5] are commonly associated with conotruncal heart defects (CHD) characterized by abnormalities of the ventricular outflow tracts and aortic arch. These heart deficiencies include lesions such as tetralogy of Fallot, pulmonary atresia, ventricular septal defect interrupted aortic arch type B (IAA) and truncus arteriosus (TA) [6]. Microdeletions of chromosomal region 22q11.2 are actually more considered as a principal cause of Di George syndrome [7, 8], velocardiofacial syndrome [9] and conotruncal anomaly face syndrome [10, 11]. The haploinsufficiency of $22 q 11$ has been found also in some familial cases of heart disease $[8,12]$ and in sporadic patients with isolated CHD [13-17].

Few cases of DGS and VCFS were associated with a microdeletion 10p13-14 [18]. This microdeletion has been also reported in other clinical features with staturoponderal and psychomotor retardations, facial dysmorphism, urinary tract abnormalities, small ears and cardiac conotruncal anomalies [19, 20].

We propose the following hypothesis that conotruncal isolated congenital heart defects could be caused by microdeletion $22 q 11.2$ and $10 q 13-14$ or chromosomal abnormalities in Algerian patients. The aim of our study is genetic analysis by using fluorescent metaphasic chromosomes in situ hybridisation to screen for the microdeletion 22q11 (DGS1) and microdeletion 10p13 (DGS2) in Algerian patients with sporadic and isolated conotruncal cardiac malformations.

Material and methods. Patients. Seventy patients, 31 males and 39 females (ranging age from 1 to 28 years) were included in the study. All patients were 
referred from the cardiology center and pediatrics cardiology center of University hospitals in Algiers. Cardiac malformations diagnosis was confirmed by echocardiography, by cardiac catheterization in all the cases studied and $95 \%$ of patients underwent surgical intervention. The patients were enrolled during their annual check in health control after their heart surgery. Most of cardiac anomalies detected in our patients were tetralogy of fallot, isolate or associated, interventricular communication isolated alone or associated and other cardiopathies (Table 1). For all analyzed patients, the thymus was present, T-lymphocytes counts and the calcemia were normal. During the clinic visit, a clinical survey was conducted and the family history was negative for the presence of the conotruncal heart disease in our patients. The staturoponderal retardation (25\%) was only one extracardiac anomaly. The cardiac anomalies or the live conditions are probably the cause of this clinical anomaly.

Table 1. Main clinical on the 70 patients

\begin{tabular}{|c|c|c|c|c|c|c|c|}
\hline Patient & Gender & Age (years) & $\begin{array}{l}\text { Congenital } \\
\text { heart defect }\end{array}$ & Patient & Gender & Age (years) & $\begin{array}{l}\text { Congenital } \\
\text { heart defect }\end{array}$ \\
\hline 1 & M & 10 & TOF & 36 & M & 14 & VSD \\
\hline 2 & M & 11 & TOF & 37 & M & 4 & VSD \\
\hline 3 & $\mathrm{~F}$ & 17 & TOF & 38 & $\mathrm{~F}$ & 18 & VSD \\
\hline 4 & M & 18 & TOF & 39 & $\mathrm{~F}$ & 3 & VSD \\
\hline 5 & $\mathrm{~F}$ & 16 & TOF & 40 & M & 2 & VSD \\
\hline 6 & M & 12 & TOF & 41 & M & 11 & VSD \\
\hline 7 & $\mathrm{~F}$ & 18 & TOF & 42 & M & 8 & VSD \\
\hline 8 & M & 7 & TOF & 43 & $\mathrm{~F}$ & 15 & VSD/ASD \\
\hline 9 & $\mathrm{~F}$ & 13 & TOF & 44 & $\mathrm{~F}$ & 13 & VSD/ASD \\
\hline 10 & $\mathrm{~F}$ & 16 & TOF & 45 & M & 6 & VSD/PA \\
\hline 11 & $\mathrm{~F}$ & 3 & TOF & 46 & $\mathrm{~F}$ & 9 & $\mathrm{VSD} / \mathrm{PA}$ \\
\hline 12 & M & 13 & TOF & 47 & $\mathrm{~F}$ & 5 & $\mathrm{VSD} / \mathrm{PA}$ \\
\hline 13 & $\mathrm{~F}$ & 18 & TOF & 48 & M & 8 & $\mathrm{VSD} / \mathrm{PA}$ \\
\hline 14 & $\mathrm{~F}$ & 15 & TOF & 49 & $\mathrm{~F}$ & 1 & PA \\
\hline 15 & M & 12 & TOF & 50 & $\mathrm{~F}$ & 10 & PA \\
\hline 16 & $\mathrm{~F}$ & 16 & TOF & 51 & M & 7 & PA \\
\hline 17 & M & 15 & TOF & 52 & $\mathrm{~F}$ & 12 & PA \\
\hline 18 & $\mathrm{~F}$ & 10 & TOF & 53 & $\mathrm{~F}$ & 15 & ASD \\
\hline 19 & $\mathrm{~F}$ & 18 & TOF & 54 & M & 24 & ASD \\
\hline 20 & $\mathrm{~F}$ & 4 & TOF & 55 & M & 22 & ASD \\
\hline 21 & $\mathrm{~F}$ & 18 & TOF & 56 & M & 4 & ASD \\
\hline 22 & M & 15 & TOF & 57 & $\mathrm{~F}$ & 12 & TGA \\
\hline 23 & $\mathrm{~F}$ & 17 & $\mathrm{TOF} / \mathrm{PA}$ & 58 & $\mathrm{~F}$ & 16 & TGA \\
\hline 24 & $\mathrm{~F}$ & 10 & $\mathrm{TOF} / \mathrm{PA}$ & 59 & M & 28 & TGV \\
\hline 25 & $\mathrm{~F}$ & 4 & TOF/AS & 60 & $\mathrm{~F}$ & 4 & TGV \\
\hline 26 & $\mathrm{~F}$ & 13 & $\mathrm{TOF} / \mathrm{PA}$ & 61 & $\mathrm{~F}$ & 11 & $\mathrm{COA}$ \\
\hline 27 & M & 3 & $\mathrm{TOF} / \mathrm{PA}$ & 62 & M & 11 & $\mathrm{COA}$ \\
\hline 28 & $\mathrm{~F}$ & 4 & VSD & 63 & $\mathrm{~F}$ & 17 & $\mathrm{COA}$ \\
\hline 29 & $\mathrm{~F}$ & 7 & VSD & 64 & M & & $\mathrm{COA}$ \\
\hline 30 & $\mathrm{~F}$ & 12 & VSD & 65 & $\mathrm{~F}$ & 8 & $\mathrm{COA}$ \\
\hline 31 & M & 6 & VSD & 66 & M & 10 & $\mathrm{COA}$ \\
\hline 32 & M & 1 & VSD & 67 & M & 12 & TA \\
\hline 33 & $\mathrm{~F}$ & 8 & VSD & 68 & $\mathrm{~F}$ & 5 & TA \\
\hline 34 & M & 2 & VSD & 69 & $\mathrm{~F}$ & 6 & AS \\
\hline 35 & M & 12 & VSD & 70 & M & 13 & AS \\
\hline
\end{tabular}

Note. M - male; F - female; TOF - tetralogy of Fallot; PA - pulmonary atresia; VSD - ventricular septal defect; ASD - atrial septal defect; TGA - transposition of the great arteries; $\mathrm{C}_{\mathrm{O}} \mathrm{A}$ - coartation of the aorta; TA - truncus arterious; AS - aortic stenosis. 

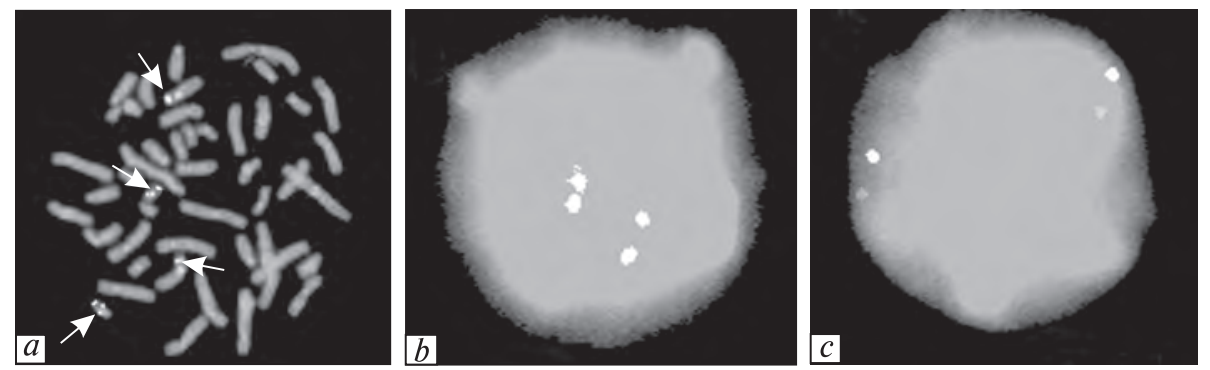

Fluorescent in situ hybridization preparation of metaphase cells $(a)$ and nuclei $(b, c)$ from a patient with conotroncal cardiac anomalies: VSD/ASD. The normal chromosomes 22 and 10 had 4 signals representing respectively the D0832 and SD10P1 which map the Di George crucial, the DAC9 chromosome 22 control probe and D10Z1 chromosome 10 control probe

GTG technique. Chromosomes were prepared from phytohemaglutinin (PHA) stimulated peripheral lymphocytes, using standard techniques for a trypsine giemsa banding (GTG band).

FISH analysis. The probes provided by Scambler were used for FISH on G0-G1 interphase nuclei and on metaphsic chromosomes spreads. The D0832 and SD10P1 which map the Di George crucial region (respectively 22q11.2 and 10p13-14) were combined with DAC9 chromosome 22 control probe and D10Z1 chromosome 10 control probe. The probes were labelled with digoxigenin, biotin or fluochrome by nick translation. Slides were pretreated with RNAse for 1 hour at $37^{\circ} \mathrm{C}$, dehydrated in series of ethanol baths $(75,90,100 \%)$, denatured for $5 \mathrm{~min}$ at $75{ }^{\circ} \mathrm{C}$ in $70 \%$ formamide and newly re-dehydrated in series of cold ethanol baths $(75$, $90,100 \%)$. The probes were also denatured at $75^{\circ} \mathrm{C}$ and put in contact with on denatured chromosomes slides for in situ hybridisation. After overnight hybridization at $37{ }^{\circ} \mathrm{C}$ in a moist chamber, the slides were washed and incubated with anti-digoxigenin fluorescein and anti-biotin antibodies at $37{ }^{\circ} \mathrm{C}$ for $30 \mathrm{~min}$. The slides were mounted with antifade solution. To visualize the fluorescence signals on the chromosomes, a cytovision probe fluorescence microscope equipped with an appropriate fluorescence filter sets was chosen. For detecting hemizygoty on $22 \mathrm{q} 11$ and $10 \mathrm{p} 13-14$, at least 20 metaphases and 10 nuclei were analysed with each probe for each patient.

Results. A detailed list of the congenital heart defects detected in our patients is shown on (Table 1). Tetralogy of Fallot isolated $(31,5 \%)$ or associated $(7,1 \%)$, ventricular septal defect isolated $(21,5 \%)$ or additional cardiac anomalies $(8,5 \%)$ are the most frequent form of congenital heart diseases. Chromosomes were apparently normal by standard technique (400 band levels) in all analysed metaphases. Fluorescent hybridization analysis has showed two hybridisation signals on chromosomes 22 with probe DO832 and on chromosomes 10 with probe DZ10P, among in all analyzed patients (Figure).

Discussion. The progress of molecular biology and more particularly application of FISH are in favour of a number more and more growing by cytogenetic abnormalities at children having a congenital heart disorder. Different chromosomal modifications such copying 1p34.1-34.2, 9p13 $\rightarrow$ ppter, $19 \mathrm{q} 13 \rightarrow 19 \mathrm{qter}$, microdeletions $6 \mathrm{q} 22.1-23.2,8 \mathrm{p} 23.1$, 9q34.3, 15q21-22.2, 16 q21-22, 19p13 $\rightarrow$ pter and others are involved in syndromic congenital heart disorders but also in isolated CHD [21]. However, after the trisomy 21 , the microdeletion $22 \mathrm{q} 11.2$ remains the most frequent second chromosomal

Table 2. Comparison of the proportion of marriage consanguine in the $\mathrm{CDH}$ and in the general population

\begin{tabular}{l|c|c|c|c}
\hline \multicolumn{1}{c|}{ Index } & $\begin{array}{c}\text { CDH } \\
\text { group }\end{array}$ & $\begin{array}{c}\text { Gene- } \\
\text { ral } \\
\text { popu- } \\
\text { lation, } \%\end{array}$ & $\chi^{2}$ & $\mathrm{P}$ \\
\hline $\begin{array}{l}\text { Marriage First } \\
\text { cousins }\end{array}$ & $\begin{array}{c}32,8 \% \\
(23 / 70)\end{array}$ & 22 & 4,808 & $0,028(\mathrm{~S})$ \\
$\begin{array}{l}\text { Marriage Con- } \\
\text { sanguineous } \\
\text { (Other lien) }\end{array}$ & $\begin{array}{l}14,2 \% \\
(10 / 70)\end{array}$ & 11,3 & 0,6225 & $0,430(\mathrm{NS})$ \\
Total & $\begin{array}{l}47 \% \\
(33 / 70)\end{array}$ & 33,3 & 6,039 & $0,014(\mathrm{~S})$ \\
& & & \\
\hline
\end{tabular}

Note. S - significant; NS - not significant. 
abnormality detected in child's congenital heart disorders. The majority of the bearing patients of the syndrome of Di George $(70-90 \%)$ or of the syndrome VCF introduce a microdeletion of identical size about $3 \mathrm{Mb}$ in the region 22q11.2 [8, 22]. This last is also linked to strongly variable phenotypes defined by different cardiac insulated pathologies such as transposition of the great arteries [23], tetralogy of Fallot [24], and pulmonary atresia [25]. However, according to different reports the proportion of congenital heart disorders not isolated linked with this microdeletion vary between $0.9-2 \%$ $[26,24]$ and $20-50 \%$ [14]. The microdeletion reduced in 1,5 Mb doesn't implicate an intermediate phenotype; the correlation genotype-phenotype is therefore difficult to establish [27].

The chromosomal abnormalities of number or of structure and microdeletions are absent in our patients with a congenital isolated heart disorder. Our results confirm the observations brought back by some authors concluding that congenital heart disorders isolated are hardly the consequence of microdeletion 22q11.2 [6, 12, 28, 29] or of microdeletion 10p13-14 [30].

The cardiac pathologies are hardly the prerogative to chromosome aberrations and of microdeletions. Indeed, the development of the molecular biology techniques allowed the identification of a number of genes involved in these pathologies and it also introduces an important monogenic heterogeneity among these diseases. The absence of the transcription factor $T B X 1$ which is encoded by a gene located in the critical region 22q11.2 appears to be responsible for cardiac defects [31]. The recessive mutations of the gene $N k \times 2.5$ which encodes the transcription factor are detected in 3-4\% patients with various cardiac anomalies like the tetralogy of Fallot, the ventricular septal defect, the atrial septal defect and the tricuspid valve abnormality [32]. These results suggest that genes $N K X 2.5$ and $T B X 1$ play an important role in the development of cardiac structure. The mutations of the gene GATA4 encoding a transcription factor that interacts with the factor $N k \times 2.5$ are involved in the ventricular septal defect and the atrial septal defect [33-35]. The mutation with incomplete penetrance of the gene ZIC3 located on chromosome X is reported in patients with transposition of great vessels [36]. Two $C F C 1$ mutations are also detected in patients with transposition of great vessels or double outlet right ventricle [37].
The mutations in the gene that encodes the MYH6 myosin heavy chain 6 and the genes activated by TBX5 and GATA4 are detected in obviousness in interauricular communications [38]. The mutations of genes CRELD1, ALK2, BMPR2, Notch1 [39, 40, 41] and PROSIT 240 [42] have been identified in the different cardiac pathologies.

All these data show the complex molecular ways involved in the cardiac morphogenesis and the importance of some genes mutations in the genesis of the non-syndromic cardiac pathology. These mutations can be dominant autosomal in variable entrance, recessive autosomal or linked to the $\mathrm{X}$ chromosome.

It is no more to show that as consanguinity increases risks of pathologies appearance linked to gene mutations and more particularly to autosomal recessive mutations [43]. Interestingly, our present study showed a significant correlation between consanguinity and congenital heart disorders $(P=0,014)$. These results are in agreement with results reported Saudi Arabia [44], in Lebanon, [45] or in India [46]. Our results are emphasize the important role played by the segregation of recessive genes in the offspring in the etiology of CHD, there is an urgent need to educate the public about the deleterious effects of inbreeding, particularly in Algeria as in Arab populations, where the ratio of consanguineous marriage is very high. Gene mutations and more particularly the recessive mutations in some genes involved in cardiac morphogenis could be at the origin of congenital nonsyndromic heart disorders in our Algerian patients.

Classical studies showed that congenital considered as multifactorial heart disorders are due at the same time to gene mutations and to environmental influence [47]. The supplementation of folates at the mother during periconceptionnel period is known to reduce considerably the impact of the anomalies of the neural tube responsible for anomalies of the conotroncal trunk to the embryo [48, 49]. It is important to point out that an important proportion of the parents of our patients $(21 / 70: 30 \%)$ live in disadvantageous conditions and are under feeding. These hard socioeconomic conditions also cause a maternal psychological and emotional effect which increases the risk of cardiac malformations [50].

Our present work aimed to screen for chromosomal abnormalities by using analysis of classical karyotype and Fluorescent Hybridization In Situ targeting the region 22q11.2 and 10p13-14 in Al- 
gerian patients. Our study showed the absence of these anomalies at all patients. But, interestingly according to molecular data reported on the different genes involved in the development of the conotroncal trunk, the screening of the germline mutations in some genes linked to CHD in Algerian patients in the near future will shed the light on the molecular genetics basis of this disease in Algerian population.

Conclusion. The screening of chromosomal abnormalities or microdeletions is not indicated in all patients with conotruncal heart defects. The main causes of this disease involve several biological and environmental factors and especially germline mutations in some genes involved in cardiac morphogenesis. In addition, in Algeria, the high percentage of consanguineous marriage requires genetic counseling in order to prevent these heart problems in the families at risk. The consanguineous marriage should be discouraged through health education of the public.

We thank the Dr Sari (Paediatric Cardiology), the patients and their families participating in this research, the clinical personnel involved in aspects of recruitment and clinical data collection, and the clinical and research institutions supporting this research project. We thank Dr Farid Cherbal for reading the manuscript.

\section{НЕДОПУЩЕНИЕ ХРОМОСОМНЫХ \\ АНОМАЛИЙ И МИКРОДЕЛЕЦИЙ 22q11 \\ И 10p13 У АЛЖИРСКИХ ПАЦИЕНТОВ \\ С ИЗОЛИРОВАННЫМИ

КОНОТРУНКАЛЬНЫМИ АНОМАЛИЯМИ

\section{F. Ammar-Khodja, M. Abdellali}

Хромосомные аномалии числа и структуры или микроделеции 22q11.2 и 10p13-14 считаются главными причинами врожденного порока сердца. Насколько нам известно, цитогенетические исследования врожденного порока сердца (CHD) в Алжире не проводились. В настоящей работе проведен скрининг хромосомных аномалий и микроделеций 22q11.2 и 10p13-14 в группе алжирских пациентов. Методы окраски по Гимза (GTG) и FISH были использованы для скрининга хромосомных аномалий и критичных участков 22q11.2 и 10p13-14 соответственно у 70 пациентов с несиндромным врожденным пороком сердца. GTG не выявило хромосомных аномалий по числу и структуре. Более того, изучение участков 22q11.2 и 10p13-14 не показало никаких микроделеций в хромосомах 10 и 22.
Наши исследования позволяют сделать вывод, что дефекты, вызванные врожденным пороком сердца у алжирских пациентов, не связаны ни с хромосомными аномалиями числа и структуры, ни с микроделециями 22q11.2 и 10p13-14. Впервые проведен цитогенетический анализ хромосомных аномалий и микроделеций 22q11.2 и 10p13-14 у алжирских пациентов с врожденным пороком сердца. Генетическое тестирование скрининга на наличие делеций 22q11.2 и 10p13-14 не показано у всех пациентов с врожденным пороком сердца. Кроме того, конотрункальные болезни сердца имеют многофакторную основу, такую как генетическое родство и рецессивные мутации некоторых генов, вовлеченных в кардиальный морфогенез. Проводится генетическое исследование роли близкородственных браков и некоторых генов, связанных с врожденным пороком сердца, в алжирской популяции. Это исследование будет также сфокусировано на профилактической работе в семьях с факторами риска и на важности генетического консультирования перед вступлением в брак.

\section{ABBREVIATIONS}

CHD $\quad-$ conotruncal heart diseases
DGS - Di George syndrome
VCFS - velocardiofacial syndrome
CTAFS - conotruncal anomaly face syndrome
IAA - interrupted aortic arch type B
TA - truncus arteriosus

\section{REFERENCES}

1. Hofman J.I.E., Kaplan S. The incidence of congenital heart disease and its prevalence in adults // Brit. Heart J. - 1962. - 24. - P. 557-560.

2. Johnson M.C., Hing A., Wood M.K., Watsor M.S. Chromosomes abnormalities in congenital heart disease // Amer. J. Med. Genet. - 1997. - 70. - P. 292-298.

3. Di-George A.M. Congenital absence of the thymus and its immunologic consequence: concurrence with congenital hypoparathyroidism // Immunologic Deficiency Disease in Man / Eds D. Bergsman, R.A. Good. March of Dimes Acad. press, BD: OAS IV 1: P. 116-121.

4. Shprintzen R.J., Goldberg R.B., Lewin M.L. et al. New syndrome involving cleft palate, cardiac anomalies typical facies and learning disabilities: velo-cardio-facial syndrome // Cleft palate J. - 1978. - 15. - P. 56.

5. Burn J., Takao A., Wilson D. et al. Conotruncal anomaly face syndrome is associated with a deletion within chromosome 22q11 // Amer. J. Med. Genet. 1993. - 30. - P. 822-824. 
6. Webber S.A., Hatchewell E., Barber J.S.K. et al. Importance of microdeletion of chromosomal region 22q11 as a cause of select malformations the ventricular outflou tracts and aortic arch: a three years prospective study // J. Pediatr. - 1996. - 129. - P. 26-32.

7. De La Chapelle A., Herva R., Koivisto M., Aula P. A deletion chromosome 22 can cause DiGeorge syndrome // Hum. Genet. - 1981. - 57. - P. 253-256.

8. Desmaze C., Prieur M., Amblard F. et al. Physical mapping by FISH of DiGeorge critical region (DGCR) : involvement of region in familial cases // Amer. J. Hum. Genet. - 1993. - 53. - P. 12391249.

9. Scambler P.J., Kelly D., Lindsay E. et al. Velocardio-facial syndrome associated with chromosome 22 locus // Lancet. - 1992. - 339. - P. 1138-1139.

10. Matsuoka R., Takao A., Kimura M. et al. Confirmation that the conotruncal anomaly face syndrome is associated with a deletion within 22q11.2 // Amer. J. Med. Genet. - 1994. - 53. - P. 285-289.

11. Momma K., Kondo C., Matsuoka R., Takao A. Cardiac anomalies associated with a chromosome 22q11 deletion in patients with conotruncal anomaly face syndrome // Amer. J. Cardiol. - 1996. - 78. P. 591-594.

12. Foskstuen S., Arbenz U., Artan S. et al. 22q11.2 deletions in a series of patients with non-selective congenital heart defects: incidence type of defects and parental origin // Clin. Genet. - 1998. - 53. P. 63-69.

13. Digilio M.C., Marino B., Musolino A.M. et al. Chromosome 22q11 microdeletions and isolated conotruncal heart defects // Arch. Dis. Child. - 1997. 76. - P. 79-81.

14. Goldmuntz E., Driscoll D.A., Bufard M.L. et al. Microdeletions of chromosomal region $22 \mathrm{q} 11$ in patients with congenital conotruncal cardiac defects // J. Med. Genet. - 1993. - 30. - P. 805-812.

15. Jiang L., Duan C., Chen B. et al. Association of 22q11 deletion with isolated congenital heart disease in three chinese ethnic groups // Int. J. Cardiol. 2005. - 105. - P. 216-223.

16. Scambler P.J., Carey A.H., Wyse R.K.H. et al. Microdeletions within 22q11 associated with sporadic and familial DiGeorge syndrome // Genomics. - 1992. 10. - P. 201-206.

17. Wilson D.I., Scambler P.J., Goodship J.A., Burn J. Deletion within chromosome 22q11 is a major cause of isolated heart defects and most cause of Di-George and velo-cardio-facial syndromes (abstr P16) // Proc. Brit. Pediatr. Ass. Meeting. - Warwick, 1992. - P. 7-10.

18. Daw S.C.M., Taylor C., Kraman M. et al. A common region of $10 \mathrm{p}$ deleted in Di-George and velo-cardiofacial syndromes // Nat. Genet. - 1996. - 13. P. 458-460.
19. Kinouchi A., Mori K., Ando M., Takao A. Facial appearance of patients with conotruncal anomalies // Pediatr. Jpn. - 1976. - 17. - P. 84.

20. Obregon M.G., Mingarelli R., Giannoti A. et al. Partial deletion 10p syndrome // Ann. Genet. - 1992. - 35. P. 101-104.

21. Anilkumar A., Kappanayil M., Thampi M.V. et al. Variation in prevalence of chromosome 22q11 deletion in subtypes of conotruncal defect in 254 children // Acta Paediatr. - 2011. - 100. - e97-100.

22. Edeman L., Pandita R.K., Morrow B.E. Low-copy repeats mediate the common $3 \mathrm{~Kb}$ deletion in patients with velocardifacial syndrome // Amer. J. Hum. Genet. - 1999. - 64. - P. 1076-1086.

23. Melchionda S., Digilio M.C., Mingararelli R. et al. Transposition of the great arteries associated with deletion of chromosome 22q11.2 // Amer. J. Cardiol. 1995. - 75. - P. 95-98.

24. Trainer A.H., Morrison N., Dunlop A. et al. Chromosome 22q11 microdeletion in tetralogy of Fallot // Arch. Dis. Child. - 1996. - 74. - P. 62-63.

25. Marino B., Digilio M.C., Novelli G. et al. Tricuspid atresia and 22q11 deletion // Amer. J. Med. Genet. 1977. - 72. - P. 40-72.

26. Beauchesne L.M., Warnes C.A., Connolly H.M. et al. Prevalence and clinical manifestations of 22q11.2 microdeletion in adult with selected conotruncal anomalies // J. Amer. Coll. Cardiol. - 2005. - 45. P. 595-598.

27. Lindsay E.A., Greenberg F., Shaffer L.G. et al. Submicroscopic deletions at 22q11.2: variability of the clinical picture and delineation of a commonly deleted region // Amer. J. Med. Genet. - 1995. 56. - P. 191-197.

28. Amati F., Mari A., Digilio M.C. et al. 22q11 deletions in isolated syndromic patients with tetralogy of Fallot // Hum. Genet. - 1995. - 95. - P. 479-482.

29. Debrus S., Berger G., De Meeus A. et al. Familial non syndromic conotruncal defects are not associated with a 22q11 microdeletion // Hum. Genet. - 1996. 97. - P. 138-144.

30. Voigt R., Maier-Weidmann M., Lange P.E., Haaf T. Chromosome 10p13-14 and 22q11 deletion screening in 100 patients with isolated and syndromic conotruncal heart defect // J. Med. Genet. - 2002. 39. - P. 16e.

31. Lindsay E.A., Vitelli F., Su H. et al. Tbx1 haploinsufficiency in the DiGeorge syndrome region causes aortic arch defects in mice // Nature. - 2001. 410. - P. 97-101.

32. Goldmuntz E., Geiger E., Benson D.W. NKX2.5 mutations in patients with tetrallogy of Fallot // Circulation. - 2001. - 104. - P. 2565-2568.

33. Garg V., Kathiriya I.S., Barnes R., Schluterman M.K. et al. GATA4 mutations cause human congenital 
heart defects and reveal an interaction with TBX5 // Nature. - 2003. - 424. - P. 443-447.

34. McElhinney D.B., Geiger E., Blinde J. et al. NKX2.5 mutations in patients with congenital heart disease // J. Amer. Coll. Cardiol. - 2003. - 42. - P. 16501655.

35. Okubo A., Miyoshi O., Baba K. et al. A novel GATA4 mutation completely segregated with atrial septal defect in a large Japanese family // J. Med. Genet. 2004. - 41. - P. e97.

36. Megarbane A., Salem N., Stephan E. et al. X-linked transposition of the great arteries and incomplete penetrance among males with a nonsense mutation in ZIC3 // Eur. J. Hum. Genet. - 2000. - 8. P. 704-708.

37. Goldmuntz E., Bamford R., Karkera J.D. et al. CFC1 mutations in patients with transposition of the great arteries and double-outlet right ventricle // Amer. J. Hum. Genet. - 2002. - 70. - P. 776-780.

38. Ching Y.H., Ghosh T.K., Cross S.J. Mutation in myosin heavy chain 6 causes atrial septal defect // Nat. Genet. - 2005. - 37. - P. 423-428.

39. Robinson S.W., Morris C.D., Goldmuntz E. et al. Missense mutations in CRELD1 are associated with cardiac atrioventricular septal defects // Amer. J. Hum. Genet. - 2003. - 72. - P. 1047-1052.

40. Smith K.A., Joziasse I.C., Chocron S. et al. Dominant-negative ALK2 allele associates with congenital heart defects // Circulation. - 2009. - 119. P. 3062-3069.

41. Garg V., Muth A.N., Ransom J.F. et al. Mutations in NOTCH1 cause aortic valve disease // Nature. 2005. - 437. - P. 270-274.

42. Muncke N., Jung C., Rudiger H. et al. Missense mutations and gene interruption in PROSIT240, a nov- el TRAP240-like gene, in patients with congenital heart defect (transposition of the great arteries) // Circulation. - 2003. - 108. - P. 2843-2850.

43. Abdulrazzak Y.M., Bener A., Al-Ghazali L.I. et al. A study of possible deleterious effects of consanguinity // Clin. Genet. - 1997. - 51. - P. 167-173.

44. Becker S.M., Al Halees Z., Molina C., Paterson R.M. Consanguinity and congenital heart disease in Saudi Arabia // Amer. J. Med. Genet. - 2001. - 99. P. 8-13.

45. Nabulsi M.M., Tamim H., Sabbagh M. et al. Parental consanguinity and congenital heart malformations in a developing country // Amer. J. Med. Genet. 2003. -116A. - P. 342-347.

46. Ramegowda S., Ramachandra N.B. Parental consanguinity increases congenital heart diseases in South India // Ann. Hum. Biol. - 2006. - 33. - P. 519528.

47. Adams M.M., Mulinare J., Dooley K. Risk factors for conotruncal cardiac defects in Atlanta // J. Amer. Coll. Cardiol. - 1989. - 14. - P. 432-444.

48. Hernandez-Diaz S., Werler M.M., Walker A.M., Mitchell A.A. Folic acid antagonists during pregnancy and the risk of birth defects // N. Engl. J. Med. 2000. - 343. - P. 1608-1614.

49. Shaw G.M., O'Malley C.D., Wasserman C.R. et al. Maternal periconceptional use of multivitamins and reduced risk for conotruncal heart defects a limb deficiency among offspring // Amer. J. Med. Genet. 1995. - 59. - P. 536-545.

50. Carmichael S.L., Shaw G.M. Maternal life event stress and congenital anomalies // Epidemiology. 2000. - 11. - P. 30-35.

Received 12.11.12 